\title{
The Role of the Fiscal Administrative Act in the Romanian Tax System
}

\author{
Alice Cristina Maria Zdanovschi \\ “Dimitrie Cantemir” Christian University, Bucharest, Romania, alice.zdanovsci@gmail.com
}

\begin{abstract}
Through this article we want to present the role of the fiscal administrative act in the Romanian tax system. Thus, we will define the fiscal administrative act and other institutions specific to the Romanian tax system, such as the administration of fiscal burdens by the tax authorities or the procedure for communicating the fiscal administrative act. Also, we will present the legal effects produced by this act, its traits and its conditions of form and substance, as well as its role in the Romanian tax system.
\end{abstract}

KEYWORDS: fiscal administrative act, fiscality, Romanian tax system, legal effects, tax authorities

\section{Introduction}

The new legal provisions underlying the Romanian tax system entered into force on 1 January 2016 through Law no 227/2015 regarding the Fiscal Code (The new Fiscal Code was adopted by Law no 277/2015 regarding the Fiscal Code published in the Official Gazette of Romania no 688/09.10.2015, as amended and supplemented) and Law no 207/2015 on the Fiscal Procedure Code (The new Code of Fiscal Procedure was adopted by Law no 207/2015 regarding the Tax Procedure Code published in the Official Gazette of Romania no 547/07.23.2015, as amended and supplemented).

In the new Code of Fiscal Procedure, article 1 point 1 , the legislator defines the fiscal administrative act as a "document issued by the tax authority in the exercise of the administration of taxes, duties and social contributions, in order to establish an individual situation and to produce legal effects to the person to whom it is addressed."

Regarding the notion of the fiscal administrative act, it should be noted that, over time, the Romanian doctrine (see, for example, Fanu-Moca 2013, 107-109) has expressed many criticisms regarding the old (In the old Code of Fiscal Procedure adopted by Government Ordinance no. $92 / 2003$, repealed, the fiscal administrative act is defined in art. 41 as follows: "the administrative act is an act by the competent fiscal body of legislation on the establishment, modification or termination of rights and tax obligations") definition of the fiscal administrative act proposed by the legislator. Thus, in the light of new regulations and a new (Cilibiu and Ioana 2015, 95) opinion expressed in the literature, we can see that this new definition of the legislator comes to emphasize the species character of the fiscal administrative act in relation to the administrative act, as the latter is provided by Law no 554/2004 on administrative litigation, as amended and supplemented, as "unilateral act with individual or normative nature issued by a public authority, in a public power, to organize law enforcement or law enforcement in concrete, which creates, modifies or extinguish legal relations"; also, according to the law are treated as administrative acts and "contracts from public authorities that concern the enhancement of public property, works of public interest, public services, public procurement and by special laws may provide other types of contracts subject to administrative jurisdiction of the administrative courts" (article 2, paragraph 2 letter c).

Therefore, as can be seen, the administrative act is the specific difference, regulated by the tax rules included in the branch of tax law, in order to produce legal effects generating tax rights and obligations, while the administrative act is the proximate genus, analyzed by administrative law.

Also, according to the specialized literature (Cilibiu and Ioana 2015, 96), the fiscal administrative act is a unilateral manifestation of will on the fiscal authorities to establish an individual fiscal situation, made for the purpose of birth, modification or extinguishment of tax legal relationships whose performance is guaranteed by the coercive force of the state.

Furthermore, the fiscal administrative act takes the legal nature (Fanu-Moca 2006, 110-113) of an administrative act of authority of a special, individual character, and, in accordance with the new provisions, is issued in the exercise of the administration of taxes, duties and social 
contributions, in order to establish an individual situation and to produce legal effects to the person to whom it is addressed.

Thus, corroborating the comments (See, broadly, Anghel and Bragaru 2006, 103-110; Sasu, Ţâţu and Pătroi 2008, 131-132) of the old regulations on the fiscal administrative act with the current form of its legal definition we conclude that the fiscal administrative act must fulfill the following conditions:

a) The administrative act must be issued by a public authority;

b) The legal act issued by tax authorities must meet the legal requirements in order to be considered an administrative act;

c) Public authority must also be a fiscal body (tax authority);

d) The fiscal body (tax authority), in the procedure for issuing the fiscal administrative act, must respect both the territorial competence and the material competence established by the law;

e) The act must be given in the exercise of the administration of taxes, duties and social contributions, in order to establish an individual situation and to produce legal effects to the person to whom it is addressed.

\section{The traits of the fiscal administrative act}

First, the tax administrative act is a unilateral manifestation of the will of its issuer. This particularity of the fiscal administrative act is important from the perspective of delimiting administrative acts from administrative facts. One of the most important consequences of this delimitation concerns the taxpayer's right (Article 268 of the Code of Fiscal Procedure provides for the right of the taxpayer's appeal against the debt instrument (the fiscal debt title) as well as against other fiscal administrative acts if they are deemed to be harmed in their rights by a fiscal administrative act. Furthermore, the appeal is an administrative appeal, which does not remove the right of action of the person who is considered to be injured in his rights by a fiscal administrative act. Also, corroborating the provisions of the Fiscal Procedure Code with the provisions of article 7 of Law no. 554/2004 (the current regulation in the area of fiscal contentious is the Law of administrative contentious no. 554/2004, published in the Official Gazette of Romania no. 1154/12.07.2004), it appears that this appeal - the administrative appeal - is a preliminary procedure and it is mandatory to go before the court is notified with an administrative litigation) to challenge fiscal administrative acts.

Secondly, the manifestation of the will of the tax body generates legal effects, that is, rights and obligations. This feature of the fiscal administrative act distinguishes it from other manifestations of will (replies, addresses, views, etc.) that do not create rights and obligations, having an orientative character for the recipient.

Thirdly, the fiscal administrative act is a species of the administrative act, with all the consequences deriving from this qualification.

Fourthly, for an administrative act to be an administrative act of a fiscal nature, it must emerge from a fiscal body (tax authority).

Fifthly, the fiscal administrative act has an individual character.

A sixth particular feature of the tax administrative act is that it is issued in the exercise of the administration of fiscal burdens by the tax authorities.

At the same time, the provisions of art. 46 Code of Fiscal Procedure provide the written form of the fiscal administrative act, either in paper or electronic form, a requirement which constitutes an ad validity (The latin expression used in the Romanian legal system being ad validitatem) condition (Anghel and Bragaru 2006, 114) and not ad-probation (The Latin expression used in the Romanian legal system being ad probationem), and its non-compliance implies absolute nullity sanction.

Also, according to par. (2) article 46 Code of Fiscal Procedure, the fiscal administrative act issued on paper shall contain the following elements:

a) The name of the issuing tax authority;

b) The date on which it was issued and the date on which it takes effect; 
c) Taxpayer/payer identification data and, where applicable, identification data of the person empowered by the taxpayer/payer;

d) The object of the fiscal administrative act;

e) Factual reasons;

f) The legal basis;

g) The name and signature of the persons empowered by the tax authority, according to the law;

h) The signature of the empowered persons of the fiscal body, according to the law, as well as the stamp of the issuing tax body;

i) The possibility of being challenged, the deadline for filing the appeal and the fiscal body to which the appeal is lodged;

j) Statements on the hearing of the taxpayer/payer hearing.

The fiscal administrative act issued in electronic form includes the aforementioned elements, except for the signature of the authorized persons of the fiscal body, as well as the stamp of the issuing tax body, but will carry the extended electronic signature, based on a qualified certificate, or of the Ministry Public Finance, or the local public administration authority, according to the central or local issuing tax authority, as the case may be (according to the combined provisions of paragraphs 3, 4 and 5 of article 46 Code of Fiscal Procedure).

Meanwhile, according to par. (6) article 46 Code of Fiscal Procedure, the fiscal administrative act issued under the conditions of article 46 par. (2) and printed by means of a mass print center is also valid if it does not bear the signature of the empowered persons of the fiscal body and the stamp of the issuing body, if it meets the legal requirements applicable in the matter (In this respect, see, for example, the Order of the Ministry of Public Finance no. 1107/08.13.2012 regarding the issuance through the mass printing center of some administrative and procedural documents).

At the same time, it should be noted that in the light of the provisions of para. (9) article 46 Code of Fiscal Procedure (a novelty of the Fiscal Procedure Code compared to the old regulation), the fiscal administrative act is considered issued and registered with the fiscal body as follows:

a) At the date of its signing by the person empowered within the fiscal body, in the case of fiscal administrative act issued on paper;

b) At the time the document was generated, in the case of a fiscal administrative act issued on paper and printed through a mass print center;

c) At the time of the application of the extended electronic signature, in the case of an electronic administrative document issued in electronic form.

Moreover, according to par. (10) article 48 Code of Fiscal Procedure, within no more than 10 working days from the date of issuing the fiscal administrative act, the fiscal body must initiate the actions for the notification of the act (must initiate the communication procedure).

\section{The role of the fiscal administrative act}

Starting from the definition provided by the law, we can see that the role of the fiscal administrative act is to establish an individual situation and to produce legal effects to the person to whom it is addressed.

However, given the legal definition, the fiscal administrative act is issued by the tax authority in the exercise of their duties on the administration of taxes, duties and social contributions.

Furthermore, according to point 2 article 1 Code of Fiscal Procedure, by the administration of taxes, duties and social contributions, in other words, the administration of fiscal burdens, it is understood any of the activities carried out by tax authorities in relation to:

a) Tax registration of taxpayers/payers and other subjects of tax (fiscal) legal relations;

b) Declaring, establishing, controlling and collecting fiscal burdens;

c) Resolution of appeals against fiscal administrative acts;

d) Assistance/guidance to taxpayers/payers, on request or ex officio;

e) Applying sanctions under the law. 


\section{The legal effects of the fiscal administrative act}

The legal effects of the fiscal administrative act will also be related with the procedure on the administration of fiscal burdens by the tax authorities

The legal definition of the fiscal administrative act expressly states that its purpose is to produce legal effects to the person to whom it is addressed. According to the provisions of article 48 par. (1) Code of Fiscal Procedure, the tax administrative act shall take effect as soon as it is communicated to the taxpayer/payer or at a later date mentioned in the administrative act communicated under the conditions of article 47 Code of Fiscal Procedure.

In addition, the fiscal administrative act that was not communicated according to the law is not opposable to the taxpayer/payer and does not produce any legal effect. In other words, "the lack of communication of an act does not entail the nullity of the act not communicated, but it will invalidate its legal effects" (Civil decision no 433R /02.10.2014).

As a consequence, the tax administrative act must be communicated to a taxpayer/payer to whom it is binding, otherwise it will not produce legal effects. And the fiscal body must initiate the actions for the notification of the act within no more than 10 working days from the date of issuing the fiscal administrative act.

\section{The communication procedure of the fiscal administrative act}

Article 47 par. (1) Code of Fiscal Procedure expressly provides that the tax administrative act must be communicated to the taxpayer/payer to whom it is intended. And, in the situation of the taxpayer/ without a domicile in Romania, who has appointed himself an empowered person according to article 18 par. (4) Code of Fiscal Procedure, as well as in the case of the appointment of a fiscal curator, under article 19 Code of Fiscal Procedure, the fiscal administrative act shall be communicated to the empowered person or the curator, as the case may be (By way of exception to the provisions of paragraph (1), paragraph (18) article 47 Code of Fiscal Procedure, provides that in case of insolvency or dissolution companies, according to the law, the communication of the fiscal administrative act shall be made to the judicial administrator / liquidator in the place indicated by him/her whenever requested in writing).

Regarding the communication procedure, the law (as provided in Article 47 Code of Fiscal Procedure) distinguishes between the communication of the fiscal administrative act issued on paper and the communication of the fiscal administrative act issued in electronic form.

Thereby, according to par. (15) article 47 Code of Fiscal Procedure, the fiscal administrative act issued in electronic form shall be communicated by electronic means of distance transmission whenever the taxpayer/payer has opted for this method of issuance and communication and shall be deemed to be communicated within 15 days from the date of transmission of the document to the taxpayer/payer or their empowered person or curator.

Furthermore, according to par. (15) article 47 Code of Fiscal Procedure, the fiscal administrative act issued on paper may be communicated either by post, or by surrender at the fiscal domicile of the taxpayer/payer or his/her empowered person or curator, or by surrender at the headquarters of the fiscal body.

Firstly, according to par. (3) article 47 Code of Fiscal Procedure, the fiscal administrative act issued on paper shall be communicated to the taxpayer/payer or to his empowered person or curator at the fiscal domicile by post, with registered letter with acknowledgment of receipt.

If communication was not possible in this way, this will be done through advertising under the terms of the law, according to par. (4) article 47 Code of Fiscal Procedure.

According to par. (5) article 47 Code of Fiscal Procedure, the communication through advertising is made by displaying an announcement stating that the fiscal administrative act has been issued in the name of the taxpayer/payer, as follows:

a) In the case of fiscal administrative acts issued by the central fiscal body by displaying the announcement, at the same time at the headquarters of the issuing tax body and on the website of the National Agency for Fiscal Administration; 
(b) In the case of fiscal administrative acts issued by the local tax authority by displaying the announcement, at the same time at the headquarters of the issuing tax authority and on the website of the respective local public administration authority.

This announcement shall be kept for at least 60 days from the date of its publication and shall contain the following (according to par. (6) article 47 Code of Fiscal Procedure):

a) The surname and forenames or the name of the taxpayer/payer;

b) The tax domicile of the taxpayer/payer;

c) The name, number and date of issue of the fiscal administrative act.

If the fiscal administrative act is communicated through advertising, it shall be considered communicated within 15 days from the date of the announcement (according to par. (7) article 47 Code of Fiscal Procedure).

Secondly, according to par. (8) article 47 Code of Fiscal Procedure, by way of exception to the provisions of paragraph (3), the competent fiscal body may decide to communicate the fiscal administrative act issued on paper by surrender, under signature, at the tax domicile of the taxpayer/payer or his / her empowered person or curator, through the employees of the fiscal body.

If in this situation of communication the addressee refuses to receive the document or is not found at the tax domicile, a notice shall be displayed on his/her door (according to par. (9) article 47 Code of Fiscal Procedure).

Thus, according to par. (10) article 47 Code of Fiscal Procedure, if the taxpayer/payer or his/her empowered person or curator refuses to receive the fiscal administrative act, the act shall be deemed to have been communicated on the date of the notice.

But, if they are not found at the fiscal domicile, the taxpayer/payer or his authorized representative or curator is entitled to submit, within maximum 15 days from the date of the notification of the notice, to the headquarters of the issuing tax authority for the fiscal administrative act to be communicate to them. In the event that the taxpayer/payer or his/her empowered person or curator fails to submit within this time limit, the act shall be deemed to have been communicated upon this date (according to par. (11) article 47 Code of Fiscal Procedure).

The aforementioned notice shall include (according to par. (12) article 47 Code of Fiscal Procedure):

a) The name of the issuing tax body;

b) The name and surname of the person who made the display and its function;

c) Name, surname and fiscal address of the person notified;

d) The name, the number and the date of issue of the fiscal administrative act in connection with which the notification is made;

e) Year, month, day, and time when the impression was made;

f) Mention of the date when the fiscal administrative act is considered to be communicated, according to par. (10) or (11) article 47 Code of Fiscal Procedure;

g) The signature of the person who posted the notice.

Thirdly, according to par. (13) article 47 Code of Fiscal Procedure, the fiscal administrative act issued in paper form may also be communicated by surrender, under signature, to the headquarters of the issuing tax body whenever the taxpayer/payer or the empowered person or the curator presents themselves at the headquarters of the fiscal body and requests this.

Finally, according to par. (12) article 47 Code of Fiscal Procedure, whenever the communication is made by advertising or by displaying the notice, the fiscal body shall draw up a report. The report is also drawn up when the taxpayer/payer or their empowered person or curator receives the fiscal administrative act, but refuses to sign the delivery receipt or, for good reason, cannot sign it.

\section{Conclusion}

The fiscal administrative act has an important place within the Romanian tax system, it can be considered a "basic cell" of the tax system. And, for its role to be accomplished, thereby to establish an 
individual situation and to produce legal effects to the person to whom it is addressed, it must exist legally not just physically, in other words, it must be communicated according to the law.

\section{References}

Anghel, Tanţi and Bragaru, Mihai. 2006. Fiscal Procedure Code. Annotated. Bucharest: Rosetti Publishing House.

Cilibiu, Octavia Maria and Ioana Victor Cristian. The notion of fiscal administrative act in the light of the new Code of Fiscal Procedure, article in the Journal - Annals of "Constantin Brâncusi" University of Târgu Jiu, Juridical Sciences Series, no 4/2015, http://www.utgjiu.ro/revista/jur/pdf/2015-04/11_doc.pdf.

Fanu-Moca, Adrian. 2006. Fiscal Contentious. Bucharest: C. H. Beck Publishing House.

Fanu-Moca, Adrian. 2013. Fiscal Contentious. Second Edition. Bucharest: C. H. Beck Publishing House.

Sasu, Horațiu, Țâţu Lucian and Pătroi Dragoș. 2008. Tax Procedure Code. Comments and Explanations. Bucharest: C. H. Beck Publishing House.

Civil decision no 433R /02.10.2014, Ilfov Tribunal, Civil Section.

Government Ordinance no 92/2003 regarding the Code of Fiscal Procedure, repealed, republished in the Official Gazette of Romania no 513 of July 31, 2007.

Law no 207/2015 regarding the Tax Procedure Code, published in the Official Gazette of Romania no. 547 of 23 July 2015.

Law no 277/2015 regarding the Fiscal Code, published into Official Gazette of Romania no 688/10.09.2015.

Law no 554/2004 of administrative contentious, published in the Official Gazette of Romania no. 1154/12.07.2004.

Order of the Ministry of Public Finance no 1107/08.13.2012 regarding the issuance through the mass printing center of some administrative and procedural documents, published in the Official Gazette of Romania no. 598/08.21.2012. 